
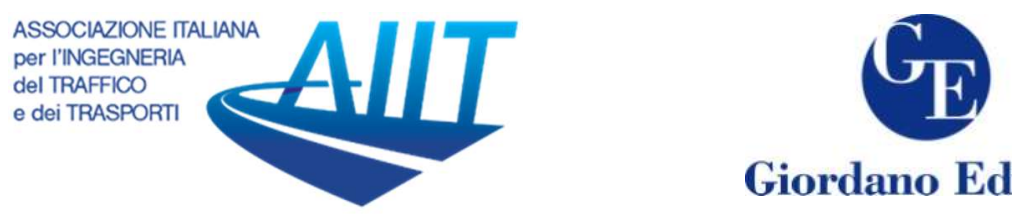

Giordano Editore

\title{
Impact of Regional Air connectivity on Regional Economic Growth in India
}

\author{
Brajesh Mishra $^{1 *}$, Fateh Bahadur Singh ${ }^{2}$, Ronak Batra ${ }^{3}$ \\ ${ }^{I}$ Research Scholar, Public Policy \& Governance, Management Development Institute Gurgaon, India \\ ${ }^{2}$ Research Scholar, Department of Management, Career Point University Kota University, India \\ ${ }^{3}$ Research Scholar, Organizational Behavior, Management Development Institute Gurgaon, India
}

\begin{abstract}
In this study, we have used the panel data of 15 federal states to evaluate the empirical linkages between regional economic growth, air transport traffic, and surface transport indicators. There is a dearth of academic articles focusing on inter-dependence between these factors in the context of India. Pedroni panel cointegration, FMOLS, panel VECM causality techniques, and variance decomposition analysis have been used to evaluate dynamics between the three variables. The evaluation of linkages between the regional air connectivity and the regional economic growth holds practical implications since it forms the basis of various policy and regulatory measures instituted in the Indian air transport sector. The bidirectional relationship between air transport and surface transport indicators calls for making multi-modal studies by experts as guiding force behind planning processes instead of relying purely on bureaucratic consultation.
\end{abstract}

Keywords: Indian air transport industry; multi-modal transport; panel data, cointegration tests; remote and regional air connectivity; gross state domestic product

\section{Introduction}

It is crucial to understand how the macro-environment operates in respect of civil aviation industry as it assists in the framing of policies by identifying areas where policy intervention could result in improved performance of aviation sector (Itani and Mason, 2014). The information on productivity linked to the air transport system may be utilized to estimate the optimum socio-economic capacity and for figuring out the elements of the enabling environment. World over, during the last two decades, the use of public service obligations, in the form of regulation and subsidies, in the aviation industry has witnessed upswing (Merkert and Williams, 2013). The emergence of a stronger aviation industry during the last few decades is believed to have resulted in employment generation, overall economic development and catalyzing benefits to trade, tourism and other linked sectors through an increase in investment, productivity, access to a broader market, consumer welfare, and better supply chain and improved connectivity of remote areas. It has also

\footnotetext{
*Corresponding author: Brajesh Mishra (fpm18brajesh_m@mdi.ac.in)
} 
brought improvement in medical supplies and humanitarian aid during natural calamities. The passengers traveling by air transport in 2018, approximately 4.5 , billion are around $50 \%$ of the global population (ATAG, 2020). The aviation sector supports the generation of 65.5 million jobs (10.2 million direct jobs), while the worldwide impact on GDP amounts to 2.7 trillion USD, including 704 billion USD by the aviation sector directly.

The growth of the air transport sector is mostly attributed to a slew of regulatory reforms. The factors that have driven these regulatory transformations are - (i) emergence of commercial reality, resulting in a trend of trans-nationalization, globalization, and liberalization; (ii) widening of regulatory objectives to cover newer economic aspects rather than restricting to the interests of national carriers (Lyle, 1995). However, the transport reforms in different countries exhibit varied shades ranging from restructuring, deregulation to privatization. The transport reforms broadly convey three main lessons (i) privatization is most effective when the competitive conditions are sustainable; (ii) incentives linked to transport reform is highly related to economic growth since growth demands for better quality and quantity of transport services cannot be delivered by state enterprise; (iii) acceptance of new role by government results in better reforms outcomes. How a government deal with reform failures in the aviation sector also becomes essential as it influences future decisions on the role of the private sector in financing, operations, and investments (Oster and Strong, 2000).

The deregulation in the aviation sector is often critiqued for the shortfall in the extent of competition as initially projected. For instance - a shortfall in the level of competition in many air routes, entry barrier faced by new players, many airlines tacitly cooperate to increase prices above marginal costs, privatization is generally linked to performance improvement alone, and adverse impact on pricing in case of inadequate numbers of competing operators (Forsyth, 1998).

Improvement in air connectivity is an essential objective of air transport industry, which is also in line with Article 44 of Chicago Convention, 1944, namely, "meet the needs of the peoples of the world for safe, regular, efficient and economical air transport" (ICAO, 2019). Equality of opportunity forms another hallmark in the development of air transport services internationally.

Indian air transport sector is ranked fifth after the US, China, Ireland, and the UK in terms of air passenger traffic. In contrast, its performance on revenue tonne-kilometers (ranked twentieth) has a substantial scope of improvement (World Bank, 2017). Given the importance of the air transport industry, the Indian government has taken several policies and regulatory initiatives (since the 1990s) in the aviation sector. The private sector role is now allowed to participate through financing, operations, and investments actively. Realizing the multiplier effect that air connectivity may bring in on the socioeconomic growth of any region, the Indian policymakers have given due importance to the promotion of remote and regional air transport. They instituted the route dispersal guideline in 1994 to regulate and promote air connectivity on commercially non-routes by private airlines. The lack of adequate response from private air service providers to operate in regional and remote areas forced the policymakers and regulators to come out with Regional ${ }^{1}$ and Remote Area Air Connectivity ${ }^{2}$ policy in 2014 policy and National

\footnotetext{
1 Regional air connectivity is defined as air transport services within and between regions which are under-served or un-served (RRAAC, 2014).

2 Remote air connectivity is defined as air transport services to areas with difficult terrain, strategic locations that lack adequate connection through surface transportation (RRAAC, 2014).
} 
Civil Aviation Policy ${ }^{3}$ in 2016. These policy measures are expected to enhance economic activities in regional and remote areas and thereby alleviate poverty and bring improvement in the living standards of the common populace (RRAAC, 2014).

The objective of this study is to mainly evaluate linkages between the regional air connectivity and the regional economic growth as it forms the basis of various policy and regulatory measures instituted in Indian air transport since the 1990s. A set of panel cointegration tests and panel regression modeling has been adopted to analyze dynamics between regional economic growth (state-specific gross domestic product), regional air connectivity (state-specific aircraft movement traffic), and surface transport traffic (represented by total state-specific registered motor vehicles). The outcome of this research is expected to have useful policy implications to justify the continuation of greater regulatory focus on regional air connectivity.

A brief about the structure and performance of the aviation industry is given in section 2. A brief literature review is covered in section 3. The methodology adopted in this study is contained in section 4 . A brief on policy / regulatory governance framework is given in section 5, while the measures taken for promotion of regional connectivity are covered in section 6. The global best practices on the regulation of the aviation industry and analysis/discussion are covered in sections 7 and 8, respectively. The section 9 deals with the conclusion on the study.

\section{Literature Review}

The research articles on the Indian air transport sector may be broadly grouped under (i) regulatory reforms, (ii) industry performance, (iii) regional air connectivity, and (iv) empirical research.

\subsection{Regulatory reforms}

The articles on regulatory reforms have mainly focused on the evolution of the air transport sector in the pre-liberalization and post-liberalization era. They also deal with various policy and regulatory measures, which lead to the emergence of low-cost carriers and one of the highest degrees of competition in the post-liberalization period (Hooper, 1997; Saraswati, 2001a; John et al., 2013; Nagpal and Sarang, 2017). This section has also covered a few that research articles carrying empirical analysis to evaluate dynamics among air connectivity parameters vis-à-vis other socio-economic factors.

Hooper (1997) assessed the Indian civil aviation sector's evolution, starting from preindependence to early post-liberalization. The author emphasized that the main obstacle faced by the industry is linked to inappropriate government policies, particularly the requirement for airlines to allocate their capacity on unprofitable routes. The liberalization initiative of the Indian government, particularly the open-sky policy around the late 1980s, could not deliver on expected lines due to abrupt regulatory reforms in the early 1990s (Saraswati, 2001a). The articles on the performance of the air transport sector have also covered technological obsolescence and opposition to private participation by staff unions. John et al. (2013) have attributed financial underperformance of carriers to outdated regulatory policies, foreign ownership restrictions, over-taxation on fuel, and overcapacity. This underperformance raises more eyebrows since it nullifies favorable

3 Its objective is to 'take flying to the masses' by making air travel affordable, revival of existing airports, setting up of new airports and viability gap funding support (NCAP, 2016). 
demographics, a large middle-class population with high disposable income, rapid economic growth, and a comparatively low penetration level in air transport. Nagpal and Sarang (2017) commended the evolution of Indian civil aviation, crediting it to postliberalization measures taken up starting the 1990s and mentioned about the projections as per which Indian aviation market is expected to become third-largest by 2020 .

\subsection{Industry performance}

The articles grouped under industry performance have emphasized on transformation of air transport industry to essential infrastructure; the importance of supply-side of domestic air services, the emergence of various opportunities and challenges; harsh markets conditions due to an intense price war, overcapacity issues and higher fuel prices intense; airport infrastructure issues; cargo solutions for industry and economic corridors; public ownership potentials; training and skill development; aircraft leasing and financing business (Saraswati 2001b; O'Connell and William, 2006; Bansal, Khan and Dutt, 2008; Saranga and Nagpal, 2016; Pratap and Chakrabarti, 2017; Banerjee, 2017; Goyal, 2008; Jaiswal, Verma and Singh, 2018; Shah and Chugan, 2019).

Saraswati (2001b) emphasized the gradual transformation of the air transport industry from an elitist mode of transportation to an essential infrastructure for the socio-economic development of society. O'Connell and William (2006) used a survey method to examine how the new regulatory roadmap has transformed the supply side of domestic air services. The study revealed that passengers opting for full-service airlines and low-cost carriers form two distinct markets. The full-service airlines were preferred by customers who valued schedule and reliability to a greater extent. Bansal, Khan, and Dutt (2008) have discussed the status, challenges, and opportunities that emerged due to the economic liberalization of air transport industry in India. The authors argued that the compulsion to match low-cost carrier's airfare and the resulting decline in revenue amid an escalation of costs is the biggest challenge. The infrastructure deficit (created by unprecedented growth), long waiting time, and lower utilization of aircraft (due to congestion), increase in aviation turbine fuel cost, lack of skilled and qualified human resources are a few critical challenges to overcome. Saranga and Nagpal (2016) have labeled the Indian aviation market as among the most challenging markets due to an intense price war and overcapacity issues and higher fuel prices. The authors identified a few regulatory factors that may adversely impact airline performance and concluded that technical efficiency plays a vital role in the achievement of better market performance.

Pratap and Chakrabarti (2017) have emphasized the growing popularity of public, private partnership approach for infrastructure development across various sectors, including the development of airports. Banerjee (2017) argued that the success of industrial and economic corridors demanded enabling environment of different air cargo solutions and cautioned that the idea of new or stand-alone cargo facilities should be resorted to only when essential and when it has a robust business case. Goyal (2008) identified factors responsible for weakness in public transport organizational, particularly related to ownership, management structure, social norms, incentives, and leadership. The author suggested for institutional structure with special incentives to reduce corruption, increase motivation, and thereby improve productivity. Jaiswal, Verma, and Singh (2018) emphasized that skilled workforce forms the backbone of the air transport sector for ensuring the safe running of airlines and, therefore, the Government of India must look into workforce planning, training needs, and related infrastructure. Shah and Chugan 
(2019) articulated that activities of aircraft leasing firms have increased substantially; however, over the last two decades, this leasing industry has moved to eastern nations (China in particular) due to stable financial markets and active role by the States.

\subsection{Regional air connectivity}

The regional air connectivity group of articles have described the current policy and regulatory measures that are likely to strengthen the regional air transport industry substantially (Singh, Dalei and Bangar Raju, 2015; Lee, 2016; Abeyrante, 2018). Singh, Dalei, and Bangar Raju (2015) have investigated various initiatives by GoI to improve regional connectivity by developing greenfield and low-cost airports. They identified region-wise airports that may be set as greenfield and the low-cost airport, and thereby enhance regional connectivity. Lee (2016) has discussed the growth potential in the air transport industry and articulated that the imbalanced evolution of regulation has restricted even faster possible expansion. The two policies by the Indian government, namely the consolidated FDI Policy, 2016, and National Civil Aviation Policy 2016, are slated to remove many of the constraints and result in faster growth. Abeyratne (2018) has argued that although the Indian aviation industry liberalization started in 1990, the restrictions due to complicated bureaucracy, foreign investment, and international operations continued. The National Civil Aviation Policy 2016 is slated to bring in ease of doing business, allowing 100\% FDI, easy airfare regulations, favorable conditions for low-cost carriers, and fair competition.

\subsection{Empirical research}

A few research articles have empirically analyzed dynamics among air connectivity parameters vis-à-vis other socio-economic factors (Backx, Carney and Gedajlovic, 2002; Merkert and Williams, 2013; Hanaoka et al., 2014; Itani and Mason, 2014; Saranga and Nagpal, 2016; Alsumairi and Tsui, 2017; Wang, Zhang and Zhang, 2018).

Backx, Carney and Gedajlovic, (2002) used academic articles to develop a hypothesis and then tested them by using panel data on a sample of medium/ large international airlines (scheduled) during the period 1993-1997. The ownership and service performance data have been applied to a series of ordinary least square regression models. Merkert and Williams (2013) used a two-stage Data Envelopment Analysis approach to assess the efficiency of 18 European PSO airlines for two financial years. The impact of specific airline details and their PSO contracts on respective efficiency have also been analyzed. Hanaoka et al. (2014) have applied the air transport market model (bi-level) used to examine the behavior of passengers as well as airlines. Itani and Mason (2014) utilized 52 country-level data on 17 input variables and four output variables (passenger traffic, air connectivity, aviation employment, and aviation contribution to GDP). They applied Structural Equation Modelling to relate them. Saranga and Nagpal (2016) collected data, from primary and secondary sources, on a variety of important parameters related to all the airlines operating in India for the period 2005 to 2012. They carried a two-stage empirical analysis by estimating operational efficiencies using Data Envelopment Analysis and then identified performance drivers using a Tobit model and two-way random effects GLS regression. Alsumairi and Tsui (2017) have employed BoxeJenkins SARIMA-X models to forecast the arrival of international tourists in Saudi Arabia. The monthly data regarding arrivals of international tourists to Saudi Arabia from 
July 2010 to December 2015, and seven explanatory variables have yielded accurate forecasting modeling with lower error values. Thus, the introduction of LCCs in the Gulf region's aviation market has increased its international tourism.

Wang, Zhang, and Zhang (2018) carried out multiple econometric analyses in their comparative study of Indian and Chinese civil aviation sector. Findings related to India indicate that LCC's presence in a route results in a reduction of airfare and stimulus to air travel demand; airport concentration is found to have a positive association with the demand for air traffic. Thus, only two out of seven studies (namely Saranga \& Nagpal, 2016 and Backx, Carney and Gedajlovic, 2002), discussed above, have covered the Indian air transport sector in their econometric analysis.

\subsection{Research gap}

It can be said the there is a shortage of research articles that have explored the interdependence between regional economic growth, performance indicators of the air transport sector, and surface transport. Further, the panel data econometric approach has been used only by Backx, Carney, and Gedajlovic, (2002). In contrast, other researchers have relied on data envelopment, Tobit, Seasonal Auto-Regressive Integrated Moving Average with exogenous factors (SARIMA-X), Structural Equation Model, and transport market model. We have used a panel data approach to ensures the availability of an increased number of data points, derive better efficiency in the model estimation and account for individual heterogeneity. We propose to make use of a set of panel cointegration tests and panel regression modeling to analyze dynamics between regional economic growth, regional air connectivity, and surface transport traffic (represented by total state-specific registered motor vehicles). The research outcomes are expected to have useful policy implications to justify the continuation of greater regulatory focus on regional air connectivity. Further, the evaluation of linkages between the regional air connectivity and the regional economic growth holds practical implications since it forms the basis of various policy and regulatory measures instituted in the Indian air transport sector.

\section{Data Description}

This study has used balance panel data of 15 federal states (or geographical administrative regions) over the period 2011-12 to 2017-184. The 15 federal states are Andhra Pradesh, Bihar, Chhattisgarh, Delhi, Himachal Pradesh, Jharkhand, Karnataka, Maharashtra, Odisha, Rajasthan, Sikkim, Tamil Nadu, Telangana, Uttar Pradesh, and West Bengal.

The starting year, 2011-12, of the data set coincides with the switchover of annual gross domestic state domestic product (at factor cost and constant price) to the base year 201112. Moreover, the time-series data range from 2011-12 to 2017-18 is selected based on the availability of a complete dataset on annual gross domestic state domestic product, annual number of registered vehicles, and aircraft movement traffic. There were 29 federal states and 7 Union Territories as on 31 March 2018. The selection criteria of these federal states included (i) No division or merger to have taken place (Telangana and Andhra

4 2011-12 represent the financial year from $1^{\text {st }}$ April 2011 to $31^{\text {st }}$ March 2012 while 2017-18 represent the financial year period spanning from $1^{\text {st }}$ April 2017 to $31^{\text {st }}$ March 2018. 
Pradesh excluded since Telangana was carved out of Andhra Pradesh on 2 June 2014), (ii) Spread across the country, (iii) availability of complete state-wise data5; (iv) significant air traffic ${ }^{6}$.

The data on annual gross state domestic product at factor cost and constant price with the base year 2011-12 (value in 100 thousand INR) is obtained from the official website of Reserve Bank of India, the central bank of India (RBI, 2019). The data on aircraft movement (annual and state-wise) is obtained from the web portal of IndiaInfrastat. The IndiaInfrastat is an organization which provides secondary socio-economic statistics about India, its federal states, and sectors (Indiastat, 2019). The data on the total count of registered motor vehicles (state-wise) has been taken from the web portal of Government of India, Ministry of Statistics and Programme Implementation (MOSPI, 2019). LGSDP, LTRAFFIC, and LRMVTH are the value obtained after taking the logarithmic transformation of the state-specific annual gross domestic product, aircraft movement traffic, and the total number of registered vehicles, respectively.

\section{Methodology}

Cointegration is a systematic co-movement between two or more non-stationary series in long-run. It is a special case of regression technique to overcome spurious regression between two or more variables, particularly when they are non-stationary, i.e. I(1) in nature. A time series which is non-stationary at level but stationary at first difference is termed as non-stationary I(1) series.

Panel data ensures the availability of an increased number of data points and hence better efficiency in model estimation. Panel data techniques allow us to account for individual heterogeneity. In other words, it will enable accounting for variables that cannot be observed/ measured, for instance, the difference in business practices across companies; or variables that change over time but not across entities. The assessment strategy adopted is outlined below.

\subsection{Descriptive Statistics}

The statistical characteristics of the panel data and its correlation matrix are presented in Table 1 and Table 2, respectively. There is a strong positive correlation among LGSDP, LTRAFFIC, and LRMVTH at 1\% level of significance, particularly between LGSDP and LTRAFFIC (0.98).

5 eight states of North Eastern Region, namely, Assam, Arunachal Pradesh, Nagaland, Manipur, Tripura, Mizoram, Meghalaya and Sikkim, and another state Kerala excluded since number of vehicles registered data was not available separately/completely.

6 all the 7 Union Territories except for Delhi excluded, Uttarakhand, Himachal Pradesh and Jammu \& Kashmir excluded. 
Table 1: Descriptive Statistics

\begin{tabular}{lrrr}
\hline & LGSDP & LTRAFFIC & LRMVTH \\
\hline Mean & 7.53 & 4.67 & 3.69 \\
Median & 7.63 & 4.66 & 3.81 \\
Maximum & 8.29 & 5.64 & 4.48 \\
Minimum & 6.05 & 3.72 & 1.56 \\
Std. Deviation & 0.49 & 0.58 & 0.67 \\
Skewness & -1.42 & 0.06 & -1.89 \\
Kurtosis & 5.13 & 1.54 & 6.56 \\
Jarque-Bera & 55.03 & 9.38 & 117.78 \\
Probability & 0.00 & 0.01 & 0.00 \\
Observations & 105 & 195 & 105 \\
\hline
\end{tabular}

Note: This table contains descriptive statistics for LGSDP, LTRAFFIC, and LRMVTH.

Table 2: Correlation between LGSDP, LTRAFFIC, and LRMVTH

\begin{tabular}{lrrr} 
& LGSDP & LTRAFFIC & LRMVTH \\
\hline LGSDP & 1.00 & $0.98^{* * *}$ & $0.71^{* * *}$ \\
LTRAFFIC & $0.98^{* * *}$ & 1.00 & $0.63^{* * *}$ \\
LRMVTH & $0.71^{* * *}$ & $0.63^{* * *}$ & 1.00 \\
\hline Note $* * *$ indicates significant at $1 \%$ level & & &
\end{tabular}

Note: $* * *$ indicates significant at $1 \%$ level.

\subsection{Panel unit root}

Here we shall apply panel unit roots tests suggested by Levin, Lin, and Chu (2002), Im, Pesaran, and Shin (2003), Maddala and Wu (1999) on each data series. The t-statistics, W-statistics, and Chi-Statistics, are applied both for trend and intercept settings. While the Levin, Lin, and Chu test use a pooled estimation, the Im, Pesaran, and Shin test utilizes heterogeneous panel techniques. The Maddala and $\mathrm{Wu}$ (PP and ADF) tests demonstrate panel unit root techniques that are non-parametric.

\subsection{Panel cointegration tests}

The Pedroni tests are inspired by Engle-Granger (1987), residual-based, cointegration tests. The Engle-Granger cointegration test examines the residuals of regression performed using $\mathrm{I}(1)$ variables. The $\mathrm{I}(0)$ nature of residuals indicate cointegration relationship between the variables.

Different individual effects have been evaluated through the Pedroni panel cointegration test (Pedroni, 1999; Pedroni, 2004) to assess cross-sectional interdependence. This test assists in drawing long-run relationships among the threepanel data series, namely, LGSDP, LTRAFFIC, and LRMVTH. The model is represented as :

$$
\operatorname{LGSDP}_{i t}=\alpha_{i}+\delta_{i} \mathrm{t}+\gamma_{1 t} \mathrm{LTRAFFIC}_{i t}+\gamma_{2 t} \mathrm{LRMVTH}_{i t}+\varepsilon_{i t}
$$

where $i=1,2 \ldots .15$ represent each regional state and $t=1,2 \ldots . .7$ represent the yearly period. The $\alpha$ is the fixed effect specific to the regional state, $\delta$ stands for deterministic time trend. At the same time, $\gamma$ 's are the variables representing elasticities of the respective data series (natural logarithmic values) to which they are shown prefixed in equation (1). The $\varepsilon$ 
represents variation related to the long-run relationship. The null hypothesis of Pedroni heterogeneous panel cointegration test states that no cointegration exists $\left(\rho_{i}=1\right)$. The unit root test performed on residual error is represented by:

$\varepsilon_{i y}=\rho_{i} \varepsilon_{i t}-1+w_{i t}$

The Pedroni heterogeneous panel cointegration test relates to the panel within a dimension (consisting of four statistics, namely, panel v-statistics, panel rho-statistics, panel PP-statistics, and panel ADF-statistics), and group between dimension (composed of three statistics, namely, group rho-statistics, group PP-statistics, and group ADFstatistics). While panel within a dimension is characterized by heterogeneity across individual items and common time factor, the group between dimensions evaluates unit root test on residuals followed by mean of individual AR coefficients of residuals.

\subsection{Estimation of panel cointegrating regression}

After establishing the heterogeneous panel cointegration, the next step involved the estimation of cointegration parameters in the long-run. The fully modified OLS (FMOLS) technique, proposed by Pedroni (2001) and Pedroni (2004), has been employed for the estimation of long-run panel cointegration parameters. The FMOLS technique is selected for the estimation purpose since Dynamic OLS proposed by Kao and Chian (2000), based on parametric panel (grouping data over the within dimension), does not take into account the cross-sectional heterogeneity.

\subsection{Panel VECM causality}

Once the panel cointegration is established, there arises the possibility of unidirectional and bidirectional causality among LGSDP, LTRAFFIC, and LRMVTH (Granger, 1969). For this, the panel VECM model suggested by (Pesaran, Shin, and Smith, 1999) has been evaluated, which incorporates both long-run and short-run variations to changes in LGSDP, long-run coefficients and error correction speed from disequilibrium.

$$
\begin{aligned}
& \Delta \mathrm{LGSDP}_{i t}=\alpha_{1 i j}+\sum_{k=1}^{q} \beta_{11 i k} \Delta \mathrm{LGSDP}_{i t-k}+ \\
& \sum_{k=1}^{q} \delta_{12 i k} \Delta \text { LTRAFFIC }_{i t-k}+ \\
& \sum_{k=1}^{q} \phi_{13 i k} \Delta \mathrm{LRMVTH}_{i t-k}+\gamma_{1 i} \varepsilon_{i t-k}+v_{1 i t} \\
& \Delta \text { LTRAFFIC }_{i t}=\alpha_{2 i j}+\sum_{k=1}^{q} \beta_{21 i k} \Delta \text { LGSDP }_{i t-k}+ \\
& \sum_{k=1}^{q} \delta_{22 i k} \Delta \text { LTRAFFIC }_{i t-k}+ \\
& \sum_{k=1}^{q} \phi_{23 i k} \Delta \mathrm{LRMVTH}_{i t-k}+\gamma_{2 i} \varepsilon_{i t-k}+v_{2 i t} \\
& \Delta \mathrm{LRMVTH}_{i t}=\alpha_{3 i j}+\sum_{k=1}^{q} \beta_{31 i k} \Delta \mathrm{LGSDP}_{i t-k}+ \\
& \sum_{k=1}^{q} \delta_{32 i k} \Delta \text { LTRAFFIC }_{i t-k}+ \\
& \sum_{k=1}^{q} \phi_{33 i k} \Delta \mathrm{LRMVTH}_{i t-k}+\gamma_{3 i} \varepsilon_{i t-k}+v_{3 i}
\end{aligned}
$$

where $\varepsilon$ represents lagged error in equations (3) to (5), which evaluates the long run deviation for the long-run equilibrium of indicated variables. While F-statistics is used to measure short-run causality, the $t$ statistics have been used to assess the significance of short-run Granger causality. 


\section{Empirical Analysis and Discussion}

The descriptive statistics are covered in section 4.1.

\subsection{Panel unit root results}

The results of the panel unit root test at the level and first difference are summarized in Table 3. The Levin, Lin \& Chu test, Im, Pesaran, and Shin test, ADF test, and PP test statistics, included in Table 3, indicate that LGSDP, LTRAFFIC, and LRMVTH are majorly nonstationary at the level while stationary in the first difference at $1 \%$ significance level. Thus, all these data series are of I(1) in nature.

Table 3: Panel Unit Root tests

\begin{tabular}{|c|c|c|c|}
\hline Variable & $\begin{array}{l}\text { Coefficient } \\
\text { (At level) }\end{array}$ & $\begin{array}{c}\text { Coefficient } \\
\text { (First Difference) }\end{array}$ & $\begin{array}{l}\text { Included in test } \\
\text { equation }\end{array}$ \\
\hline \multicolumn{4}{|c|}{ Levin, Lin \& Chu t-stat } \\
\hline LGSDP & $5.39(1.00)$ & $-17.17 * * *(0.00)$ & Individual intercept \\
\hline LTRAFFIC & $8.11(1.00)$ & $-9.47 * * *(0.00)$ & Individual intercept \\
\hline LRMVTH & $30.48(1.00)$ & $-5.62 * * *(0.00)$ & None \\
\hline \multicolumn{4}{|c|}{ Im, Pesaran and Shin $W$-stat } \\
\hline LGSDP & $7.29(1.00)$ & $-9.61 * * *(0.00)$ & Individual intercept \\
\hline LTRAFFIC & $6.08(1.00)$ & $-1.27 *(0.10)$ & Individual intercept \\
\hline LRMVTH & - & - & None \\
\hline \multicolumn{4}{|c|}{$\begin{array}{c}\text { MW test: } A D F-\text { Fisher Chi- } \\
\text { square }\end{array}$} \\
\hline LGSDP & $1.38(1.00)$ & $102.29 * * *(0.00)$ & Individual intercept \\
\hline LTRAFFIC & $0.98(1.00)$ & $40.18 *(0.10)$ & Individual intercept \\
\hline LRMVTH & $5.61(1.00)$ & $72.45 * * *(0.00)$ & None \\
\hline \multicolumn{4}{|c|}{ MW test: PP-Fisher Chi-square } \\
\hline LGSDP & $0.82(1.00)$ & $117.62 * * *(0.00)$ & Individual intercept \\
\hline LTRAFFIC & $0.69(1.00)$ & $58.12 * * *(0.00)$ & Individual intercept \\
\hline LRMVTH & $1.44(1.00)$ & $112.90 * * *(0.00)$ & None \\
\hline
\end{tabular}

Note: This table summarizes the results of four set of panel unit root tests on the three variables. ${ }^{* * *},{ }^{* *}$, and $*$ indicate significance at $1 \%, 5 \%$, and $10 \%$, respectively.

\subsection{Panel cointegration tests}

Having established the I(1) nature of LGSDP, LTRAFFIC, and LRMVTH, the Pedroni panel cointegration is applied on the three-panel data series against three deterministic specifications, namely, individual intercept, individual intercept and individual trend, and no intercept or trend. The test results have been summarized in Table 4. Results from another panel cointegration test, suggested by Kao (1999), are also included in Table 4. The null hypothesis of 'no cointegration' is rejected by the majority of the panel cointegration tests, thereby establishing that LGSDP, LTRAFFIC, and LRMVTH exhibit long-run relationship. 
Table 4: Panel Cointegration tests results

\begin{tabular}{|c|c|c|c|c|}
\hline \multirow{3}{*}{ Statistics Name } & \multicolumn{3}{|c|}{ Pedroni (Engle-Granger based) Panel Test } & \multirow[t]{2}{*}{ Kao Panel Test } \\
\hline & \multicolumn{3}{|c|}{ Deterministic trend specification } & \\
\hline & $\begin{array}{c}\text { Individual } \\
\text { intercept }\end{array}$ & $\begin{array}{c}\text { Individual } \\
\text { intercept and } \\
\text { individual trend }\end{array}$ & $\begin{array}{c}\text { No intercept of } \\
\text { trend }\end{array}$ & $\begin{array}{l}\text { Individual } \\
\text { intercept }\end{array}$ \\
\hline Panel v-Statistic & $-0.49(0.69)$ & $6.94 * * *(0.00)$ & $-2.94(0.99)$ & \multirow{8}{*}{$\begin{array}{c}\text { ADF t-Stat } \\
-5.14 * * *(0.00)\end{array}$} \\
\hline Panel rho-Statistic & $1.40(0.92)$ & $2.39(0.99)$ & $1.59(0.95)$ & \\
\hline Panel PP-Statistic & $-4.86 * * *(0.00)$ & $-10.63 * * *(0.00)$ & $1.86(0.097$ & \\
\hline Panel ADF-Statistic & $-4.23 * * *(0.00$ & $-7.97 * * *(0.00$ & $2.59(0.99)$ & \\
\hline Group rho-Statistic & $2.69(0.99)$ & $4.59(1.00)$ & $4.23(1.00)$ & \\
\hline Group PP-Statistic & -14.58 & $-17.30 * * *(0.00)$ & $4.91(1.00)$ & \\
\hline & $* * *(0.00)$ & & & \\
\hline Group ADF-Statistic & $-8.94 * * *(0.00)$ & $-6.92 * * *(0.00)$ & $6.02(1.00)$ & \\
\hline Inference & Cointegration & Cointegration & No Cointegration & Cointegration \\
\hline
\end{tabular}

Note: This table summarizes the results of Pedroni panel cointegration tests against the three deterministic trend specifications. The Kao panel test with individual intercept trend specification is also mentioned.

\subsection{Panel cointegrating regression estimation}

After establishing long-run cointegrating relationships among LGSDP, LTRAFFIC, and LRMVTH, the panel cointegration estimation model suggested by Kao, Chiang, and Chen (1999), has been applied. The trend specifications used in the fully modified OLS technique are - 'Pooled' for level panel method, six for the long-run variances kernel bandwidth.

Table 5: Fully modified OLS results

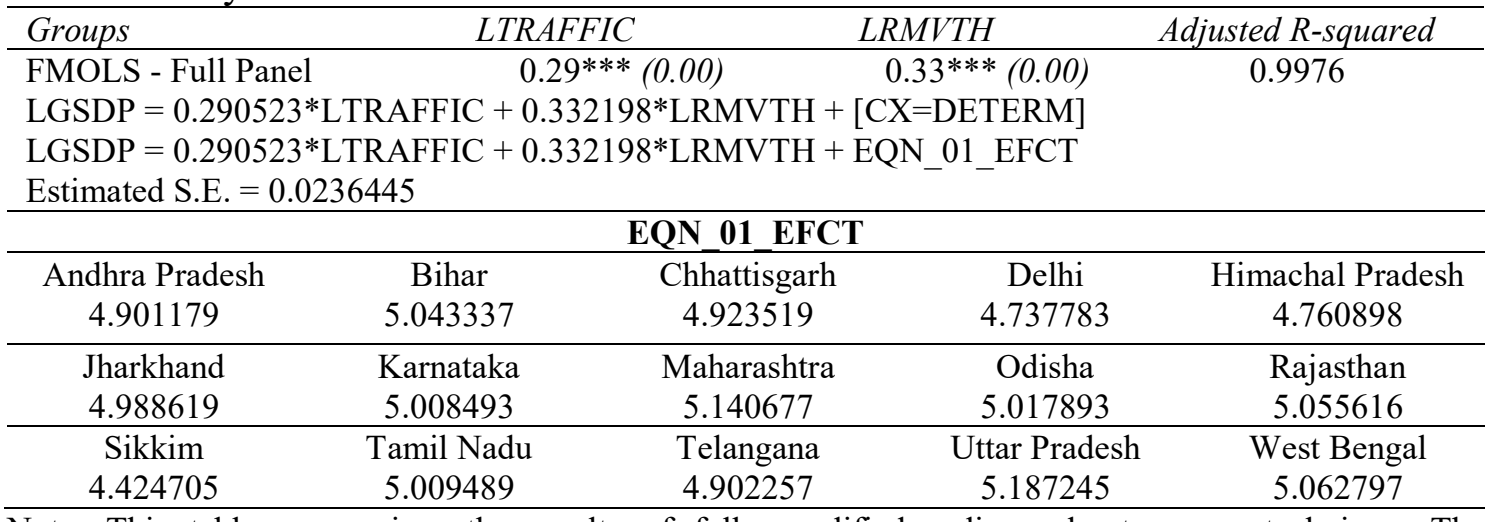

Note: This table summarizes the results of fully modified ordinary least square technique. The $\mathrm{CX}=\mathrm{DETERM}$ demonstrate the presence of heterogeneous trend term in the cointegration relationship.

The results presented in Table 5 indicate that for full panel scenario, both aircraft movement traffic and the total number of registered vehicles have a positive impact on state gross domestic product at 1\% level of significance. The effect of the total number of registered vehicles representing surface transport traffic is greater as compared to aircraft movement traffic. A 10\% increase in aircraft movement traffic shall increase state gross domestic product by $2.9 \%$, while a $10 \%$ increase in surface transport traffic shall lead to an increase in state gross domestic product by $3.3 \%$. The CX=DETERM term in the model demonstrates the presence of heterogeneous trend terms in the cointegration relationship. This term for a specific state is lowest for Sikkim (4.42), Delhi (4.73), and Himachal Pradesh (4.76), which indicates the dominance of the combined effect of air transport and surface transport. Their dominance may be explained by the fact that while 
Delhi is the national capital of India, Sikkim and Himachal Pradesh are a popular destination for domestic and international tourists. The trend term for a specific state is highest for Uttar Pradesh (5.18), Maharashtra (5.14), and West Bengal (5.06), closely followed by Rajasthan (5.05) and Bihar (5.04). It implies that gross domestic products of these states are dominated by components other than air transport and surface transport. It indicates scope for increasing the contribution of air and surface transport components in the state-specific domestic products in the case of these states.

\subsection{Panel VECM Causality}

Table 6 represents the summary of the long run and short run granger causality using the VECM model.

Table 6: Results of VECM Granger Causality

\begin{tabular}{|c|c|c|c|c|c|c|}
\hline & \multicolumn{4}{|c|}{ Sources of causation (independent variables) } & \multirow{2}{*}{$\begin{array}{l}\text { Independent } \\
\text { variable }\end{array}$} & \multirow{2}{*}{$\begin{array}{l}\text { Long-run } \\
\text { causality\# } \\
\text { to LGSDP } \\
\text { Chi-square }\end{array}$} \\
\hline $\begin{array}{l}\text { Dependent } \\
\text { variable }\end{array}$ & $\begin{array}{c}\Delta \text { LGSDP } \\
\text { Chi- } \\
\text { square }\end{array}$ & $\begin{array}{l}\Delta \text { LTRAFFIC } \\
\text { Chi-square }\end{array}$ & $\begin{array}{l}\Delta \text { LRMVTH } \\
\text { Chi-square }\end{array}$ & $\begin{array}{l}\text { Long-run } \\
\text { ECT }\end{array}$ & & \\
\hline$\Delta$ LGSDP & - & $\begin{array}{l}7.95 * * \\
(0.02)\end{array}$ & $\begin{array}{c}10.32 * * * \\
(0.00)\end{array}$ & $\begin{array}{c}-0.0299 * * * \\
(0.00)\end{array}$ & & \\
\hline$\triangle$ LTRAFFIC & $\begin{array}{c}0.29 \\
(0.86)\end{array}$ & 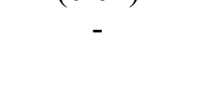 & $\begin{array}{c}6.36^{* *} \\
(0.04)\end{array}$ & $\begin{array}{c}0.0901^{*} \\
(0.06)\end{array}$ & LTRAFFIC & $\begin{array}{l}7.95 * * \\
(0.02)\end{array}$ \\
\hline$\Delta$ LRMVTH & $\begin{array}{c}3.99 \\
(0.13)\end{array}$ & $\begin{array}{c}7.26^{* *} \\
(0.03)\end{array}$ & - & $\begin{array}{c}0.0116 \\
(0.80)\end{array}$ & LRMVTH & $\begin{array}{c}10.31 * * * \\
(0.00)\end{array}$ \\
\hline
\end{tabular}

Note: This table summarizes the vector error correction model based granger causality results. Figures in parenthesis are probability values. $* * *, * *$, and $*$ indicate significance at $1 \%, 5 \%$, and $10 \%$, respectively. \# Calculated using Wald Test

The speed of adjustment for $\triangle$ LGSDP is -0.0299 at a $1 \%$ level of significance, which is low in magnitude. Long-run causality between the coefficients of lagged error terms of LTRAFFIC and LRMVTH are evaluated by the use of the Wald test, whose results are also summarized in two rightmost columns. The Wald test established a long-run relationship running from LTRAFFIC and LRMVTH to LGSDP at a $1 \%$ level of significance. From Table 6 , it is evident that short-run causality also runs from LTRAFFIC and LRMVTH to LGSDP at 5\% and 1\% level of significance, respectively. In comparison, a bidirectional causality relationship exists between LTRAFFIC and LRMVTH at a 5\% level of significance. These causality outcomes have important policy implications. Firstly, the bidirectional causal relationship between air transport and surface transport traffic justifies the multi-modal transport planning practices. In other words, planning of surface transport or air transport in silos may result in inefficient utilization or unbalance application of socio-economic resources. Ideally, the planning process should be based on a multi-modal study by subject experts instead of turning it to a bureaucratic consultation. It may not be possible to come out with a universal approach that may be applied to all federal states.

Secondly, the long term causal relationship from LTRAFFIC to LRMVTH to LGSDP establishes that air transport and surface transport play an essential role in state-specific gross domestic products. It has an important policy implication. It is crucial for policy formulators and regulators to understand how the macro-economic environment operates in respect of the civil aviation industry along with other modes of transport. It is in line with the findings of Itani and Mason (2014). They advocated for the identification of 
specific areas where policy intervention could result in improved performance of the aviation sector. Further, while making an air transport system plan by considering exclusive conditions linked to the industry, it is necessary to take into account the general existing and projected economic conditions, as well.

\subsection{Variance decomposition analysis}

The dynamics among LGSDP, LTRAFFIC, and LRMVTH has also been empirically examined using the variance decomposition (VD) analysis. The results obtained by running variance decomposition analysis are summarized in Table 7.

Table 7: $\quad$ Variation Decomposition

\begin{tabular}{|c|c|c|c|c|c|c|c|c|c|}
\hline \multirow[t]{2}{*}{ Year } & \multicolumn{3}{|c|}{ Panel A: VD of LGSDP } & \multicolumn{3}{|c|}{ Panel B: VD of LTRAFFIC } & \multicolumn{3}{|c|}{ Panel C: VD of LRMVTH } \\
\hline & $\underset{\Omega}{\Xi}$ & 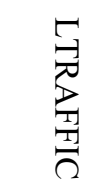 & $\underset{⿱ 乛}{ٍ}$ & $\underset{\Omega}{\tilde{\sigma}}$ & 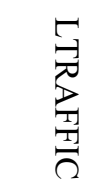 & $\underset{3}{\stackrel{5}{2}}$ & $\underset{\Omega}{\sigma}$ & 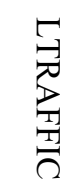 & 党 \\
\hline 1 & 100.00 & 0.00 & 0.00 & 10.66 & 89.34 & 0.00 & 5.88 & 2.54 & 91.58 \\
\hline 2 & 80.11 & 11.31 & 8.58 & 10.29 & 87.41 & 2.30 & 4.19 & 1.49 & 94.32 \\
\hline 3 & 79.21 & 12.32 & 8.47 & 12.58 & 84.63 & 2.79 & 4.95 & 1.86 & 93.19 \\
\hline 4 & 71.99 & 18.10 & 9.90 & 13.43 & 83.96 & 2.60 & 4.81 & 2.26 & 92.93 \\
\hline 5 & 68.78 & 20.49 & 10.73 & 14.52 & 83.22 & 2.26 & 4.76 & 2.55 & 92.69 \\
\hline 6 & 65.02 & 23.07 & 11.91 & 15.43 & 82.60 & 1.97 & 4.65 & 2.62 & 92.73 \\
\hline 7 & 62.34 & 24.83 & 12.83 & 16.38 & 81.91 & 1.71 & 4.61 & 2.72 & 92.67 \\
\hline 8 & 59.72 & 26.51 & 13.77 & 17.25 & 81.24 & 1.51 & 4.56 & 2.77 & 92.67 \\
\hline 9 & 57.53 & 27.85 & 14.62 & 18.11 & 80.53 & 1.36 & 4.53 & 2.79 & 92.67 \\
\hline 10 & 55.49 & 29.07 & 15.43 & 18.93 & 79.79 & 1.28 & 4.50 & 2.80 & 92.70 \\
\hline
\end{tabular}

Note: This table summarizes the variance decomposition results corresponding to shock applied in each variable. For instance - Panel A contains the percentage forecast error in the three variables as the LGSDP is subjected to shock.

The variance decomposition contains forecast error (in percentage) of each variable that can be attributed to shock in other variables over ten years. For instance, Panel A contains percentage forecast errors in LGSDP, LTRAFFIC, and LRMVTH attributed to shock in LGSDP over ten years. The first column in Panel-A, Panel-B, and Panel-C contain information on how much variability in LGSDP, LTRAFFIC, and LRMVTH respectively are explained by their own shocks at the end of each year.

A shock in LGSDP is explained by LGSDP itself (100\%) in the short run wherein LTRAFFIC and LRMVTH exhibit strong exogenous nature (feeble influence in predicting future). In the long run (after ten years), however, a shock in LGSDP is explained majorly by LGSDP $(55.49 \%)$ and partially by LTRAFFIC $(29.07 \%)$ and LRMVTH (15.43\%).

On similar lines, it may be concluded that, in the short-run, a shock in LTRAFFIC is majorly explained by LTRAFFIC itself (89.34\%), partially by LGSDP (10.66\%) and in a strong exogenous means by LRMVTH. This observation is also reflected in the long-run, wherein, a shock in LTRAFFIC is majorly explained by itself (79.79\%), endogenously by LGSDP (18.93) and extremely weak endogenously by LRMVTH (1.28\%). As far as LRMVTH is concerned, the observation of the short-run gets replicated in the long-run. Here, though the observed period, a shock in LRMVTH is majorly explained by 
LRMVTH (91-94\%) and weak endogenously by LGSDP (4-5\%) and LTRAFFIC $(1 \sim 2 \%)$.

\section{Summary and Conclusion}

In this study, we have used the panel data of 15 federal state and union territories from 2011 to 2017 to evaluate the empirical linkages between economic activities (represented by gross state domestic products), air transport traffic, and surface transport indicators. After finding that the three data variables possess I(1) nature, we have applied the Pedroni panel cointegration test to establish the existence of cointegration relationships between the three variables. Subsequently, fully modified ordinary least square (FMOLS) technique and panel vector error correction model (VECM) causality techniques have been used to estimate panel cointegration regression and study direction of causality relationships, respectively. We have established that both aircraft movement traffic and the total number of registered vehicles have a significant positive impact on gross state domestic product (GSDP). The effect of the total number of registered vehicles representing surface transport traffic on gross state domestic product $(10 \%$ increase leads to 3.3 impacts on GSDP) is greater as compared to that of aircraft movement traffic $(10 \%$ increase leads to a $2.9 \%$ impact on GDP). The Wald test has established a long-run relationship from LTRAFFIC and LRMVTH to LGSDP at a $1 \%$ level of significance. Further, we have also ascertained that short-run causality also runs from LTRAFFIC and LRMVTH to LGSDP, while a bidirectional causality relationship exists between LTRAFFIC and LRMVTH. The dynamics among the three research variables (LGSDP, LTRAFFIC, and LRMVTH) have also been examined using the variance decomposition analysis.

A few practical implications emanating for industry, policymakers, and regulators are summarized below:-

(i) Identified a few federal states, among those covered in this study, where the air transport and surface transport contributions to gross state domestic product can be improved. The top five such states are - Uttar Pradesh, Maharashtra, West Bengal, Rajasthan, and Bihar.

(ii) The bidirectional causal relationship between air transport and surface transport traffic justifies the multi-modal transport planning practices to ensure the efficient utilization of socio-economic resources.

(iii) The long term causal relationship outcomes from air transport and surface transport indicators to gross state domestic product has established the importance of understanding of the macro-economic environment by the policy formulators and regulators who are engaged in the domain of air transport sector along with other transport sectors.

(iv) Overall, this study has established the justification of increased policy and regulatory interventions to promote regional and remote area air connectivity since 2014 . These policy and regulatory measures are intended to enhance economic activities in 
regional and remote areas and thereby alleviate poverty and bring improvement in the living standards of the common populace.

The connectivity should be better described in terms of accessibility by air transport (combining notions like quality, distance, facilities, availability, and cost). Future research may capture the wider aspects of air transport accessibility. Future studies may explore the inclusion of railway transport as a variable to assess the combined effect of road, rail, and aircraft traffic on economic activities in various regions with a nation. It will give a more holistic scenario of multi-modal transport systems and their interaction with the overall macro-economic environment.

\section{References}

Abeyratne, R. (2018), "Air Transport in India: Some Legal, Regulatory and Economic Issues" Air and Space Law, 43(6), pp.543-560.

Alsumairi, M. and Tsui, K. W. H. (2017), "A case study: The impact of low-cost carriers on inbound tourism of Saudi Arabia", Journal of Air Transport Management, 62, pp.129-145.

ATAG. (2020), Air Transport Action Group. https://www.atag.org/ourpublications/latest-publications.html (Accessed 25 March 2020).

Backx, M., Carney, M. and Gedajlovic, E. (2002) "Public, private and mixed ownership and the performance of international airlines", Journal of Air Transport Management, 8(4), pp.213-220.

Banerjee, P. (2017), Development of East Coast Economic Corridor and Vizag-Chennai Industrial Corridor: Critical Issues of Connectivity and Logistics. [online] ADB South Asia Working Paper Series. https://think-asia.org/bitstream/handle/11540/8656/sawp050.pdf? sequence $=1$

Bansal, S. C., Khan, M. N. and Dutt, V. R. (2008), "Economic liberalisation and civil aviation industry", Economic and Political Weekly, pp.71-76.

Engle, R. F., \& Granger, C. W. (1987), "Co-integration and error correction: representation, estimation, and testing", Econometrica: journal of the Econometric Society, pp. 251-276.

Forsyth, P. (1998), "The gains from the liberalisation of air transport: a review of reform", Journal of Transport Economics and Policy, pp.73-92.

Goyal, A. (2008), "Governance in India's public transport systems: Comparing Indian railways and airlines", Economic and Political Weekly, pp.119-127.

Granger, C. W. (1969), "Investigating causal relations by econometric models and crossspectral methods", Econometrica: journal of the Econometric Society, pp.424-438.

Hanaoka, S., Takebayashi, M., Ishikura, T. and Saraswati, B. (2014), "Low-cost carriers versus full service carriers in ASEAN: The impact of liberalization policy on competition", Journal of Air Transport Management, 40, pp.96-105.

Hooper, P. (1997), "Liberalisation of the airline industry in India", Journal of Air Transport Management, 3(3), pp.115-123.

ICAO. (2019), International Civil Aviation Organization. https://www.icao.int/secretariat/TechnicalCooperation/Pages/history.aspx.

Im, K. S., Pesaran, M. H. and Shin, Y. (2003), "Testing for Unit Roots in Heterogeneous Panels", Journal of Econometrics, 115, pp.53-74. 
Indiainfrastat (2019), India Infrastructure Statistical Organization. www.indiainfrastat.com/transport-data/30/civil-aviation/62/total-traffic-air-craftmovement-at-airport-of-india-2002-2018/286831/stats.aspx

Itani, N. and Mason, K. (2014), "A macro-environment approach to civil aviation strategic planning”, Transport Policy, 33, pp.125-135.

Jaiswal, K., Verma, S. and Singh, B. (2018), "Preparing to lead the bandwagon: A case of growing Indian aviation industry" in 2018 Advances in Science and Engineering Technology International Conferences (ASET) IEEE, pp.1-8.

John, F. O., Krishnamurthy, P., Warnock-Smith, D., Lei, Z. and Miyoshi, C. (2013), “An investigation into the core underlying problems of India's airlines", Transport Policy, 29, pp.160-169.

Kao, C. (1999), "Spurious Regression and Residual-Based Tests for Cointegration in Panel Data", Journal of Econometrics, 90, pp.1-44.

Kao, C. and Chiang, M. H. (2000), "On the estimation and inference of a cointegrated regression in panel data", in Nonstationary Panels, Panel Cointegration, and Dynamic Panels, JAI Press, pp.179-222.

Kao, C., Chiang, M.H. and Chen, B. (1999), "International R\&D Spillovers: An Application of Estimation and Inference in Panel Cointegration", Oxford Bulletin of Economics and Statistics, 61, pp.693-711.

Lee, J. W. (2016), "India's New Foreign Direct Investment (FDI) Regime in the Airline Industry: Changes and Challenges", NUS Centre for Asian Legal Studies Working Paper, pp.1-18.

Levin, A., Lin, C. F. and Chu, C. (2002), "Unit Root Tests in Panel Data: Asymptotic and Finite-Sample Properties", Journal of Econometrics, 108, pp.1-24.

Lyle, C. (1995), "The future of international air transport regulation", Journal of Air Transport Management, 2(1), pp.3-10.

Maddala, G. S. and Wu, S. (1999), "A Comparative Study of Unit Root Tests with Panel Data and A New Simple Test", Oxford Bulletin of Economics and Statistics, 61, pp.631-52.

Merkert, R. and Williams, G. (2013), "Determinants of European PSO airline efficiencyEvidence from a semi-parametric approach", Journal of Air Transport Management, 29, pp.11-16.

MOSPI (2019), Ministry of Statistics and Programme Implementation, Government of India. http://www.mospi.gov.in/statistical-year-book-india/2018/189

Nagpal, R. and Saranga, H. (2017), "The evolution of Indian civil aviation", In Air Transport Liberalization, Edward Elgar Publishing.

NCAP(2016). National Civil Aviation Policy 2016. http://www.civilaviation.gov.in/sites/default/files/Final_NCAP_2016_15-06-2016.pdf

O'Connell, J. F. and Williams, G. (2006), "Transformation of India's domestic airlines: a case study of Indian Airlines, Jet Airways, Air Sahara and Air Deccan", Journal of Air Transport Management, 12(6), pp.358-374.

Oster, C. V. and Strong, J. S. (2000), "Transport restructuring and reform in an international context", Transportation Journal, 39(3), pp.18-32.

Pedroni, P. (1999), "Critical Values for Cointegration Tests in Heterogeneous Panels with Multiple Regressors", Oxford Bulletin of Economics and Statistics, 61, pp.653-670.

Pedroni, P. (2001), "Purchasing Power Parity Tests in Cointegrated Panels", The Review of Economics and Statistics, 83, pp.727-731. 
Pedroni, P. (2004), "Panel Cointegration; Asymptotic and Finite Sample Properties of Pooled Time Series Tests with an Application to the PPP Hypothesis", Econometric Theory, 20, pp.597-625.

Pesaran, M. H., Shin, Y. and Smith, R. P. (1999), "Pooled mean group estimation of dynamic heterogeneous panels", Journal of the American Statistical Association, 94(446), pp.621-634.

Pratap, K. V. and Chakrabarti, R. (2017), "Sectoral Distribution and Sector-Specific Issues for Infrastructure PPPs", in Public-Private Partnerships in Infrastructure, Springer, Singapore, pp.139-170.

RBI. (2019). Reserve Bank of India. https://m.rbi.org.in/Scripts/PublicationsView.aspx?id=18814

RRAAC. (2014), Policy on Regional and Remote Area Air Connectivity. http://www.civilaviation.gov.in/sites/default/files/policy\%204.pdf

Saranga, H. and Nagpal, R. (2016), "Drivers of operational efficiency and its impact on market performance in the Indian Airline industry", Journal of Air Transport Management, 53, pp.165-176.

Saraswati, S. K. (2001a), "Civil aviation environment in India”, Economic and Political Weekly, pp.1639-1645.

Saraswati, S. K. (2001b), "Operating environment for a civil aviation industry in India”, Journal of Air Transport Management, 7(2), pp.127-135.

Shah, D. and Chugan, P. K. (2019), "Aircraft Financing and Leasing in India Challenges \& Opportunities: An Exploratory Study of Developing Aircraft Financing and Leasing in India", in Rijwani, P. et al. (Eds.), Economy and Environment: Corporate Perspectives, Himalaya Publishing House Pvt. Ltd., pp.282-290.

Singh, D. P., Dalei, N. N. and Bangar Raju, T. (2015), "Economics of Air Connectivity in India during Post Regulation and Post Privatization Era", International Journal of Applied Research, 1(11), pp.673-679.

Wang, K., Zhang, A. and Zhang, Y. (2018), "Key determinants of airline pricing and air travel demand in China and India: Policy, ownership, and LCC competition", Transport Policy, 63, pp.80-89.

World Bank. (2017). ICAO Estimates on Air Transport \& Passenger Carried in year 2017, https://data.worldbank.org/indicator/is.air.psgr 